\section{The Response of Foraminifera and Ostracods Assemblages to the Sediment Properties of Southern Caspian Sea Shorelines}

\author{
Masoomeh Sohrabi Mollayousefi ${ }^{1 *}$ and Babak Moghaddasi ${ }^{2}$ \\ ${ }^{1}$ Department of Geology, Islamshahr Branch, Islamic Azad University, Islamshahr, Iran \\ ${ }^{2}$ Department of Agriculture and Natural Resources, Savadkooh Branch, Islamic Azad \\ University, Savadkooh, Iran
}

\begin{abstract}
A B S T RA C T
Foraminifera and Ostracods are regarded as ideal indices of marine pollution investigations. During spring 2017, we investigated benthic assemblage of Foraminifera and Ostracods along the Gilan province in the southern shoreline of Caspian Sea, Iran as a pioneer study throughout the country. The sampling stations were selected to cover the shoreline both extremes as well as middle parts. Different physio-chemical properties like salinity, $\mathrm{pH}$, carbonate content, sediment particle size and peculiarities were measured in the pre-defined sampling sites. Our findings show that Foraminifera and Ostracods abundance negatively dependent to the sediment particles' size while positively correlated with water carbonate content. Other macro faunal communities positively increased in their abundance where the sediment particles size show increasing trend
\end{abstract}

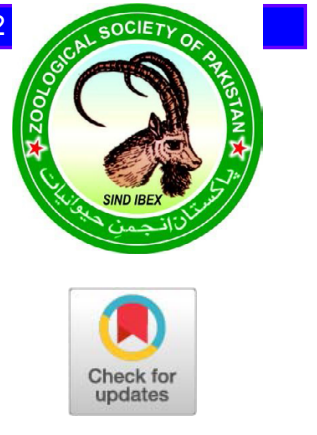

Article Information

Received 29 January 2020

Revised 02 March 2020

Accepted 13 April 2020

Available online 11 October 2021

Authors' Contribution

Both authors contributed equally

in research and writing fo the

manuscript.

Key words

Habitat affinities, Environmental

pollution, Shoreline physiography,

Macro fauna

\section{INTRODUCTION}

$\mathrm{A}$ pproximately $50 \%$ of the world's population occupies land a few hundred kilometers away from coastlines (Shuval, 2003). Therefore, a considerable human activities takes place in such a fragile ecosystems. However, the sustainability of such ecosystems can be severely compromised along developed and urbanized coastlines, and this is predominantly due to anthropogenic influences (Vitousek et al., 1997).

Benthic foraminifera are one of the most widely used bioindicators in monitoring shorelines (Alves-Martins et al., 2019), however there is paucity of information on benthic foraminiferal assemblages in the southern Caspian Sea coast. As the largest closed sea in the world, Caspian Sea has considerable biodiversity from diverse taxa. However, it suffers from intensive human activities and water pollution. Benthic organisms in every marine ecosystem like Caspian Sea play a major role in the marine communities' viability and sustainability. Such organisms not only serve vital ecosystem services but are also frequently used as model species to investigate marine pollution (Moghadasi, 2008). For instance Foraminifera has been used as bioindicators for different kinds of pollutions such as thermal (Yahiya and Miranda, 2016; Titelboim et al., 2016),

\footnotetext{
Corresponding author: sohrabi705@gmail.com 0030-9923/2021/0006-2329 \$ 9.00/0

Copyright 2021 Zoological Society of Pakistan
}

heavy metals (Baz, 2014; Youssef, 2015; Schintu et al., 2016; Raja et al., 2016), offshore oil drilling (Gyu et al., 2014; Laroche et al., 2016), toxic sediments (Martin and Nesbitt, 2015), trace metals (Li and Li, 2014; Li et al., 2015), industrial effluents (Lee and Nikraz, 2015). Foraminifera (Kingdom Protista) are found in all marine environments, either in planktic or benthic mode of life (Bellier et al., 2010). These organisms reflect environmental disturbances or stressers in different ways like changing population abundance, deformities in their external morphological peculiarities, rapid change in their assemblages and defaunation when offshore and inshore areas compared (Uthicke et al., 2012), decreased growth rate, irregular reproduction, deformed chambers and abnormalities (Nigam et al., 2009). In addition to being ideal indicators in environmental health studies, such assemblages play a major role in the marine food chains. They mainly feed on bacteria, planktons and diatoms which can be preyed upon by highly specialized micro carnivores that confirm their role as a key link in marine food chains, assimilating energy available from innate autotrophs and also retrieving energy available during the final stages of degradation of organic debris. In turn, they support a variety of larger organisms and thus contribute to the diversity and secondary productivity of ecosystems (Lipps and Valentine, 2007).

Spatial and temporal variations in the abundance of organisms of Foraminifera and Ostracods are usually controlled by the interactions of complex environmental 
factors like heavy metal content (Jones, 1964), total organic matter (Pommepuy et al., 1999; Pote et al., 2009), sediment grain size (Burton et al., 1987; Garzio-Hadzick et al., 2010), other organisms like predators or preys (Marino and Gannon, 1991; Davies et al., 1995), ambient temperature and salinit, sunlight intensity and seasonal variations (Faust et al., 1975; Davies and Evison, 1991). Such association to the specific physiological factors offers several advantages in terms of their survival and persistence from environmental stressers like UV light (Davies-Colley et al., 1999), protection from predators (Roper and Marshall, 1974), shelter from predation (Davies and Bavor, 2000) and more food resources like organic matter content compared to the water column. However, regardless of the natural phenomena like hydrological cycles, human induced factors, mainly marine transportation, marine pollution, sewage discharge, recreational activities and mechanical disturbances such as commercial dredging all have the potential to re-suspend sediment particles and their associated organisms back into the water column, resulting in periodic elevated levels of ecosystem disturbances (Grimes, 1975; Gerba and McLeod, 1976; An et al., 2002). Here, we aimed to find the relationships among the different environmental factors and some ecological peculiarities of benthic Foraminifera and Ostracods assemblages in less known Southern Caspian Sea shorelines.

\section{MATERIALS AND METHODS}

The study area is located in the southern shorelines of Caspian Sea in Gilan province between $48^{\circ} 53^{\prime}, 50^{\circ} 34^{\prime} \mathrm{N}$ and $36^{\circ} 34,3827$. The study area is characterized by annual average temperature from 6.3 to $29.8{ }^{\circ} \mathrm{C}$. The meteorological conditions of the study area mainly influenced by moderate Caspian climate and receive the most precipitation throughout the country (National Centers for Environmental Information, 2019). Mean air humidity ranges from 55 to 96 percent during a year. The existence of Alborz mountain range, direction of the mountains ridges, the elevation above sea level, and more importantly, climatic impacts from Mediterranean region and especially Caspian Sea shape the study areas' climate. Climatic types for Gilan province includes moderate climate in lowlands with an average annual rainfall of 1200-1300 mm, decreasing eastward; mountainous climate which covers northern slopes of Alborz mountainous range which receives precipitation as snowfall; arid climate with annual rainfall of $500 \mathrm{~mm}$ (Kazemi et al., 2015).

\section{Sampling and data collection}

To investigate Foraminifera and Ostracod population structure, totally 20 stations were selected in 5 line transects (Table I). Environmental factors like the amount of dissolved oxygen (DO), water salinity (WS), $\mathrm{pH}$, electric conductivity (EC), water temperature (WT) the organic content, sediment grain size, heavy metals content (copper, lead and cadmium) as well as species richness and abundance were measured in sediment samples taken from four different vertical heights of 5, 10, 15, 20 m using Van Veen Grab $100 \mathrm{~cm}^{2}$. Sampling events were repeated three times during the sampling season. To make an understanding from microbenthic communities of the sampling stations, five samples were taken using core samplers of $3.5 \mathrm{~cm}$ diameter and $7 \mathrm{~cm}$ height. Since sediments are frequently heterogeneous we tried to take several sub-samples and mixed them together in a composite sample (Darnley et al., 1995). If the interest is mainly in the fine sediment fractions $(<0.063 \mathrm{~mm})$, a sample mass of only $1 \mathrm{~kg}$ (dry weight) is sufficient in most of the cases (IAEA, 2003). Sampled sediments were stored in plastic jars and kept under the room temperature before taking to the lab. To study meiobenthic specimens, the sediment samples were exposed to the Rose Bengal stain for at least three weeks before lab analysis (Lutze and Altenbach, 1991). In the lab sediment samples were washed using $63 \mu \mathrm{m}$ sieve. Remaining material was transferred to the numbered Petri dishes, which were then placed in an oven and kept there for a minimum of $8 \mathrm{~h}$ at a temperature of $70-80^{\circ} \mathrm{C}$. While adding carbon tetrachloride, in the volume of three times more than the dried sediment volume, we stirred the mixture vigorously with a glass rod to make the buoyant air-filled Foraminifera and paired ostracod carapaces float to the surface. After pouring the liquid on the paper filters and drying them under standard conditions, we separated the organisms and counted them. Meiofauna were separated and counted using stereomicroscope and referring to the published identification keys (Loeblich and Teppan, 1988)

Table I. Sampling transects along the Gilan province shorelines.

\begin{tabular}{lll}
\hline Station name & Longitude & Latitude \\
\hline Chaboksar & $50^{\circ} 35^{\prime} \mathrm{E}$ & $36^{\circ} 57^{\prime} \mathrm{N}$ \\
Kalachai & $50^{\circ} 24^{\prime} \mathrm{E}$ & $37^{\circ} 4^{\prime} \mathrm{N}$ \\
Roudsar & $50^{\circ} 28^{\prime} \mathrm{E}$ & $37^{\circ} 13^{\prime} \mathrm{N}$ \\
Zibakenar & $49^{\circ} 87^{\prime} \mathrm{E}$ & $37^{\circ} 43^{\prime} \mathrm{N}$ \\
Gisum & $49^{\circ} 47^{\prime} \mathrm{E}$ & $37^{\circ} 67 \mathrm{~N}$ \\
\hline
\end{tabular}

Sediment grain-size composition parameters

The collected sediment samples were air-dried and sieved to separate the particles larger than $1 \mathrm{~mm}$ 
and their fractions compared to those of smaller size as determined by the sieving method and were calculated by weight percentage. Following the chemical pre-treatment procedure described by Konert and Vandenberghe (1997), $40 \mathrm{mg}$ of collected sediments were transferred to the Petri dishes and put into the oven @ 80 $\mathrm{C}$ for $8 \mathrm{~h}$. Some part of the dried sediment $(25 \mathrm{mg})$ were spilled from into a beaker containing a solution of $250 \mathrm{ml}$ distilled water, $0.5 \%$ Sodium Hexametaphosphate (SHMP), to prevent particles from aggregating. After shaking the mixture vigorously to homogenize the sample, using a shaker set at $110 \mathrm{rpm}$, the mixture was allowed to precipitate during $8 \mathrm{~h}$ at the room temperature. The beaker content was shaken for $15 \mathrm{~min}$ and dried at $80^{\circ} \mathrm{C}$. Dried particles were spilled onto the sieves of different mesh sizes $(0.063,0.125,0.25,0.5,1$, 2 and $4 \mathrm{~mm}$ ) and the finer particles were flushed through the sieves. The fraction $<63 \mu \mathrm{m}$ will go through both sieves and will be flushed down the drain. The relative weight fractions of clays and silt $(<63 \mu \mathrm{m}$, fine), sand $(<2 \mathrm{~mm}$, $>63 \mu \mathrm{m}$, medium), and gravel $(>2 \mathrm{~mm}$, coarse) were calculated then.

\section{Total organic materials (TOM)}

To measure the TOM of the sampled sediments, following the procedure described by Schumacher (2002), three replicate sediment samples from each site were pooled and homogenized. Approximately $20 \mathrm{~g}$ of fresh sediment from each sample was placed in a pre-weighed crucible and dried at $600^{\circ} \mathrm{C}$ for $8 \mathrm{~h}$. The difference between the primary samples weight and those after the $8 \mathrm{~h}$ can be used to calculate the amount of the organic matter content (weight loss after being dried). This was repeated three times using the same pooled sample to determine an overall average. Moisture content per $g$ of fresh sediment was determined by calculating the percentage difference between wet weight and dry weight after $8 \mathrm{~h}$ at $600^{\circ} \mathrm{C}$. The second weight of the dried sediment samples were measured and the TOM was calculated using the following formula:

$$
\text { (\%) } T O M=100(A-B) /(A-C)
$$

\section{Heavy metals content}

In order to determine the amount of heavy metals $(\mathrm{Cd}, \mathrm{Cu}, \mathrm{Pb}) 1 \mathrm{~g}$ of the dried sediment samples (stored in the oven at $70-80^{\circ} \mathrm{C}$ for $24 \mathrm{~h}$ ) were mixed with a mixture of concentrated acids. In this acid digestion procedure, an aliquot of samples $(1 \mathrm{~g})$ were digested in acid mixture $\left(\mathrm{HNO}_{3}=2 \mathrm{ml}, \mathrm{HClO}_{4}=2.2 \mathrm{ml}\right.$, and $\left.\mathrm{HCl}=2 \mathrm{ml}\right)$ and heated at $95{ }^{\circ} \mathrm{C}$ for $3 \mathrm{~h}$. After the digestion process, each digest was screened through the paper filters using ultra-pure water. These solutions $(50 \mathrm{ml})$ were analyzed by atomic absorption device following the manufacturer's protocol.

\section{Statistical analysis}

Using the Statistical Package for Social Sciences SPSS v20, (IBM Corp., Armonk. NY), correlations were performed using the average data calculated for each site to determine the relationships between target communities in the sediments with different tested parameters. The normal distribution of the data were tested using Kolmogorov-Smirnov test. The non-parametric Spearman Rank Correlation Coefficient $\left(r_{s}\right.$ ) was used due to the data being not normally distributed. In case of non-normal data distribution, we used Mann-Whitney U and Kruskall-Wallis $\mathrm{H}$ tests to investigate intra and interstations measured factors like heavy metal concentration and total organic matter. Spearman rank correlation coefficient analysis was applied to test the significant relationships between heavy metal concentration and morphological variables (e.g. weight and total body length). One-way ANOVA was used to compare the significant difference of the measured environmental factors among the stations. The association of the Foraminifera diversity and density in different samples were investigated using Pearson correlation test. Shanon index of diversity was used to determine Foraminifera and Ostracods diversity in different sampling stations (Magurran, 1988).

\section{RESULTS}

Totally five different species from three genera and families were identified in this survey and Ammonia beccarii $(60 \%)$ was identified as the most abundant species while the members of Rosalina (1\%) constitute the lowest abundance. The next most abundant taxon was $A$. tepida as well. Foraminifer abundance in the study area and stations is shown in Table II and Figure 1. A. beccarii was recorded mostly in Abbas Abad station while the lowest number were recorded in Nashtarud and Ramsar stations. The most number of $A$. tepida was recorded in Ramsar and Tonekabon stations. Nashtarud and Ramsar inhabited the most and lowest number of E. crispum, respectively. Totally Ramsar inhabited by lower abundance and density of Foraminifera. The same results were obtained regarding the taxa density. Pearson correlation analysis indicated that the species density has meaningful linear relationship with station depth, sediment grain patterns, percent amount of the organic matter, amount of the dissolved oxygen and electric conductivity $\left(\mathrm{R}^{2}=0.76, \mathrm{P}<0.05\right)$. Meanwhile we found negative linear correlation among the taxa density and water temperature, salinity, chrome and zinc concentration $(\mathrm{P}<0.05)$. 
Table II. The abundance of different Foraminifera species in different stations. F, G, H, I are stand for Chaboksar, Rudsar, Kalachai, Zibakenar and Gisum respectively. Subdivisions stands for different depths of $5,10,15$ and $20 \mathrm{~m}$ from sea level.

\begin{tabular}{llllll}
\hline Stations & $\begin{array}{l}\text { Ammonia } \\
\text { beccarii }\end{array}$ & $\begin{array}{l}\text { Ammonia } \\
\text { tepida }\end{array}$ & $\begin{array}{l}\text { Elphidi- } \\
\text { um }\end{array}$ & $\begin{array}{l}\text { Rosalina } \\
\text { sp. }\end{array}$ & $\begin{array}{l}\text { Abnor- } \\
\text { mal }\end{array}$ \\
\hline F5 & 577 & 300 & 135 & 45 & 17 \\
F10 & 2045 & 1249 & 285 & 7 & 35 \\
F15 & 11055 & 3429 & 2195 & 171 & 213 \\
F20 & 12587 & 3082 & 1121 & 41 & 297 \\
G5 & 3710 & 579 & 191 & 4 & 34 \\
G10 & 7542 & 5663 & 2714 & 81 & 325 \\
G15 & 5608 & 3554 & 1481 & 34 & 172 \\
G20 & 12514 & 5943 & 1054 & 120 & 401 \\
H5 & 117 & 55 & 6 & 0 & 8 \\
H10 & 1250 & 1128 & 218 & 3 & 27 \\
H15 & 5397 & 2509 & 750 & 94 & 118 \\
H20 & 14058 & 7248 & 1705 & 145 & 399 \\
I5 & 722 & 549 & 161 & 37 & 24 \\
I10 & 1394 & 1033 & 179 & 7 & 26 \\
I15 & 12577 & 5736 & 3356 & 27 & 343 \\
I20 & 12221 & 5094 & 629 & 227 & 168 \\
J5 & 325 & 172 & 58 & 12 & 4 \\
J10 & 93288 & 2055 & 616 & 13 & 75 \\
J15 & 5110 & 2462 & 476 & 30 & 106 \\
J20 & 3513 & 1948 & 757 & 8 & 262 \\
\hline & & & & &
\end{tabular}

\section{Sediment properties and granulometry}

Our data indicated that fine and very fine sand, silt and clay constitute the most part of study area's sediment structure (Table III). The most coarse sediment texture was recorded in I 20 station (mean diameter of $0.62 \mathrm{~mm}$ ) while the finest sediments were recorded in F10 sampling station (mean diameter of $0.1 \mathrm{~mm}$ ).

\section{Total organic materials (TOM)}

The percent amount of the organic matters does not show any meaningful trends among the stations. The lowest value of TOM was recorded at station F5 (1.41\%) and the maximum amount was recorded in the station I $20(6.2 \%)$ (Fig. 1). Pearson correlation analysis indicates that there is significant linear correlation between the percent mass of organic matter and Foraminifera's' abundance and density in the studied stations $\left(\mathrm{R}^{2}=0.68, \mathrm{P}<0.05\right)$. The concentration of dissolved oxygen, sediment granulite and its copper concentration facilitate taxa's presence while higher ambient acidity and temperature showed blocking effect in turn. Oneway ANOVA confirmed significant difference among the stations (like F5 vs $\mathrm{H} 15$ and I5) and inter depth regarding the total organic matters (ANOVA: $\mathrm{F}=18.4, \mathrm{P}<0.05$ ).

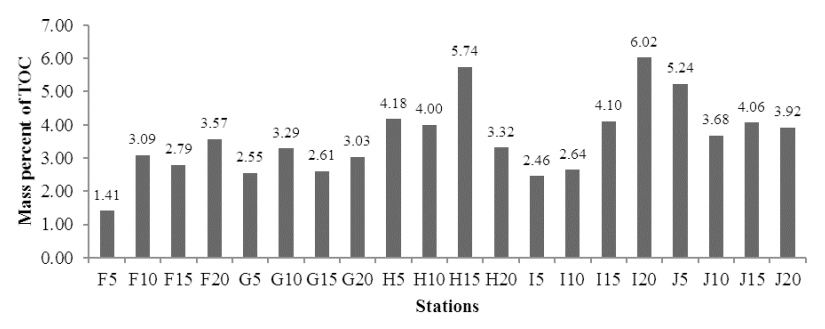

Fig. 1. The percent value of total organic materials weight in different stations. F, G, H, I are stand for Chaboksar, Rudsar, Kalachai, Zibakenar and Gisum respectively. Subdivisions stands for different depths of 5, 10, 15 and $20 \mathrm{~m}$ from sea level

\section{Heavy metal content}

Data on heavy metals concentration in different stations have been shown in Figure 2. The most mean concentration of $\mathrm{Pb}$ and $\mathrm{Cu}$ can be seen in Roudsar station $(\mathrm{H})$, while the lowest one belong to the Gisum station (J). There is no significant difference among the sampling stations regarding the $\mathrm{Pb}$ content (ANOVA: $\mathrm{F}=23.6, \mathrm{df}=80, \mathrm{P}>0.05)$. The mean concentration of $\mathrm{Pb}$ was higher in areas which showed lowest $\mathrm{pH}(\mathrm{r}=-0.6)$. The mean concentration of $\mathrm{Cu}$ was different among the stations (ANOVA: $\mathrm{F}=18.4, \mathrm{df}=80, \mathrm{P}>0.05$ ) while no significant differences were observed in different depths. The concentration of mentioned metal was higher in places with higher organic matters while having lower $\mathrm{pH}$.

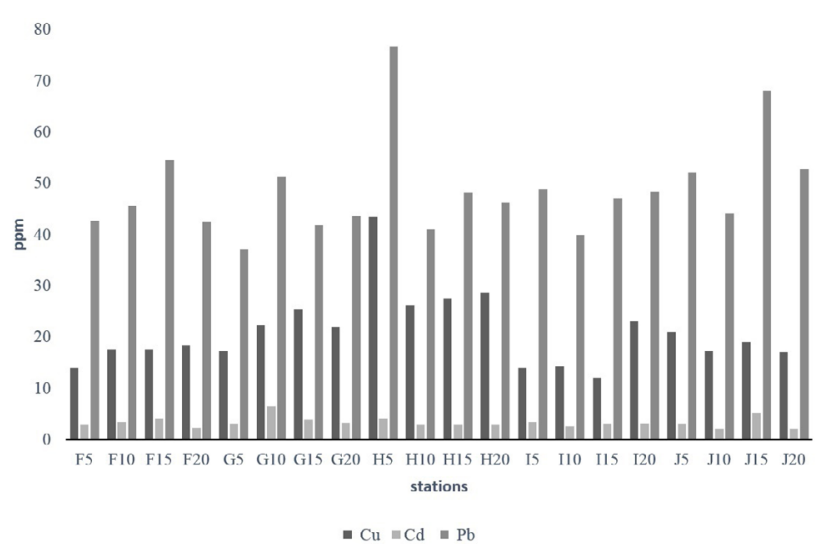

Fig. 2. Mean concentration of lead, cupper and cadmium along the Gilan costline. Subdivisions stands for different depths in each station (the acronyms are as in Fig. 1). 
Table III. Sediment particles classification in the study area.

\begin{tabular}{|c|c|c|c|c|c|c|c|c|c|}
\hline \multirow[t]{3}{*}{ Transect } & \multirow[t]{3}{*}{ Station } & \multicolumn{8}{|c|}{ Relative weight (grams) } \\
\hline & & \multicolumn{3}{|c|}{ Sand } & \multicolumn{4}{|c|}{ Fine sand } & \multirow{2}{*}{\begin{tabular}{c|}
\multicolumn{2}{c|}{ Clay silt } \\
$0.63-0$
\end{tabular}} \\
\hline & & $6-4$ & $4-2$ & $2-1$ & $1-0.5$ & $0.5-0.25$ & $0.25-0.12$ & $0.12-0.063$ & \\
\hline \multirow[t]{4}{*}{$\mathrm{F}$} & F5 & 0 & 0.1 & 0 & 0 & 0.1 & 43.96 & 47.36 & 8.5 \\
\hline & F10 & 0 & 0 & 0 & 0 & 0.2 & 10.3 & 80.1 & 9.5 \\
\hline & F15 & 0.0 & 0.8 & 0.9 & 0.8 & 10.1 & 27.3 & 53.5 & 6.2 \\
\hline & $\mathrm{F} 20$ & 0.5 & 0.2 & 0.4 & 0.6 & 2.5 & 7.6 & 68.6 & 19.6 \\
\hline \multirow[t]{4}{*}{ G } & G5 & 0 & 0 & 0 & 0 & 0 & 33.2 & 59.5 & 7.28 \\
\hline & G10 & 0 & 0 & 0.1 & 0.1 & 0.3 & 11.8 & 74.3 & 13.5 \\
\hline & G15 & 0 & 0 & 0 & 0 & 20 & 21.7 & 43.8 & 14.4 \\
\hline & G20 & 0 & 0.52 & 0.36 & 0.6 & 1.36 & 9.32 & 72.88 & 14.96 \\
\hline \multirow[t]{4}{*}{$\mathrm{H}$} & H5 & 0 & 0 & 0 & 1.4 & 14.28 & 31.4 & 40.8 & 12.12 \\
\hline & $\mathrm{H} 10$ & 0 & 0 & 0.04 & 0.28 & 4.84 & 42.88 & 44.92 & 7.04 \\
\hline & H15 & 2.44 & 1.76 & 5.44 & 10.56 & 10.12 & 19.04 & 41.04 & 9.6 \\
\hline & $\mathrm{H} 20$ & 0.56 & 1.48 & 5.12 & 17.32 & 9.56 & 15.12 & 37.36 & 13.48 \\
\hline \multirow[t]{4}{*}{ I } & I5 & 0 & 0 & 0 & 0.12 & 1.52 & 44.64 & 43.88 & 9.84 \\
\hline & $\mathrm{I} 10$ & 0 & 0.12 & 0.08 & 0.08 & 0.12 & 25.48 & 65.92 & 8.2 \\
\hline & I15 & 0 & 0.12 & 0.24 & 0.4 & 3.8 & 23.4 & 57.88 & 14.16 \\
\hline & $\mathrm{I} 20$ & 3.32 & 1.96 & 7.56 & 23.28 & 10.84 & 14.56 & 23.84 & 14.64 \\
\hline \multirow[t]{4}{*}{$\mathrm{J}$} & J5 & 0 & 0 & 0 & 0.04 & 0.28 & 37.48 & 54.52 & 7.68 \\
\hline & $\mathrm{J} 10$ & 0 & 0.04 & 0.28 & 0.36 & 9 & 25.44 & 47.88 & 17 \\
\hline & $\mathrm{J} 15$ & 0.16 & 0.36 & 1.6 & 5.2 & 5.36 & 19 & 47.6 & 20.72 \\
\hline & $\mathrm{J} 20$ & 0.04 & 1.16 & 2.68 & 1.8 & 8.04 & 21.68 & 54.2 & 10.04 \\
\hline
\end{tabular}

We found that dissolved oxygen concentration, water depth, percent amount of organic materials and sediment particle size have positive correlation with the presence and habitat selection of the target organisms. However, salinity and temperature exhibited a negative correlation with Foraminifera density and abundance. Water salinity was different significantly among the stations and in different depths $(\mathrm{P}<0.05)$, the same result was recorded about the $\mathrm{pH}$ as well. The maximum salinity was recorded in the western most part of the study area, Astara which was around $11 \mathrm{~g} / \mathrm{l}$. Ambient temperature showed highest mean in Gisum station $(\mathrm{J})$ during the study period however the highest dissolved oxygen was also recorded for this area. Kalachai sampling station $G$ host highest concentration of $\mathrm{CaCo}_{3}(34.25 \%)$ and the lowest amount was recorded for Gisum station $\mathrm{J}$ which was around $18 \%$.

\section{DISCUSSION}

Foraminifera are abundant organisms, which are widely distributed in marine environments from deep oceans to estuaries, brackish waters making the excellent subjects as bioindicators (Bellier et al., 2010). Investigations showed that factors like human induced activities, sediment particle size or sediment texture properties (Chatelet et al., 2009), and the amount of the organic matters, water salinity, ambient temperature affects these benthic organisms distribution patterns and habitat use. Ammonia beccarii was the most abundant species in nearly all stations. The next most abundant taxon was $A$. tepida which is very tolerant to the organic and chemical pollution (Gyu et al., 2014; Yahiya and Miranda, 2016; Titelboim et al., 2016; Laroche et al., 2016). The higher abundance of such a tolerant species in these areas indicates that the benthos is significantly impacted by both organic pollution and probably suffers from a greater impact of chemical pollution.

Our analysis showed that different environmental conditions in the southern Caspian Sea shorelines affect the benthic communities' density, abundance and habitat selection. Despite being not so far from each other, the texture of these sediments is generally different and, as a 
result of their autochthonous origin, the particle size is significantly different. Our findings indicate that sediment grain size and the amount of total organic materials are the most limiting parameter for benthic foraminiferal density and specie richness which are usually very low within stations with fine or very fine particles. This can be related to more oxygen penetration among the larger particle size (Smith et al., 2016). This is not however confirmed by some other researchers who believe that the density and abundance of the target organisms are very low in the coarse sediment particles (Burone et al., 2003). The percent amount of the $\mathrm{CaCO}_{3}$ showed significant correlation with sediment particle size, as the more coarse sediment particles had more calcium carbonate. The most recorded amount of $\mathrm{CaCO}_{3}$ belonged to the second station (34.25\%) and the lowest amount was equal to $18 \%$ in the sixth station. The later station sediment is derived mainly from coarse sandy particles. Higher $\mathrm{CaCO}_{3}$ in the second station can be related to the continental sediments which was entered to this area.

However, in Ramsar and Abbas Abad, the main sediment structure constituted from clay and silt while inhabiting more organisms from the order Rotalina order. This finding indicate that different taxa prefer different sediment particle size depending on their life style. Since sand constitute the principle part of the sediment texture of the study areas, it provide ideal environment for our target organisms. Dissolved oxygen and temperature are the second affecting factor which has negative linear relationship with ambient temperature. Some other studies showed that the density of Foraminifera is the lowest and the species richness is the highest in areas where the amount of organic carbon is the lowest, the value of $\mathrm{C} / \mathrm{N}$ has been reported as an effective factor in this relationship (Sadough et al., 2013).

Depending on the variability of the physicochemical variables, living assemblages of Foraminifera can be quite variable over time. As many other investigations show, benthic Foraminifera are very ideal indicators of environmental changing, especially pollution, as they react within less than one month to the conditions change (Sadough et al., 2013). Our findings indicate the importance of understanding the ecology of the benthic foraminifera species for environmental assessment of the marine and especially coastal ecosystems, and therefore for the establishment of biomonitoring procedures.

\section{ACKNOWLEDGMENT}

We are grateful to the anonymous reviewer, which helped us to improve the earlier draft of the paper. This research has been funded by Islamshahr Branch, Islamic Azad University, Islamshahr, Iran.
Statement of conflict of interest

The authors have declared no conflict of interest.

\section{REFERENCES}

Alves-Martins, M.V., Hohenegger, J., Frontalini, F., Alveirinho, Dias J.M., Geraldes, M.C. and Rocha, F., 2019. Dissimilarity between living and dead benthic foraminiferal assemblages in the Aveiro Continental Shelf (Portugal). PLoS One, 14:1-47. https://doi.org/10.1371/journal. pone.0209066

An, Y.J., Kampbell, D.H. and Breidenbach, G.P., 2002. Escherichia coli and total coliforms in water and sediments at lake marinas. Environ. Pollut, 120: 771-778. https://doi.org/10.1016/S02697491(02)00173-2

Baz, S.M.E.L., 2014. Benthic foraminifera as bioindicators of heavy metal pollution in Lake Burullus, Egypt. Arab. pp. 5491-5509. https://doi. org/10.1007/s12517-014-1611-8

Bellier, J.P., Mathieu, R. and Granier, B., 2010. Short treatise on foraminiferology (Essential on modern and fossil foraminifera). Carnets de Géologie Notebooks on Geology, Brest, pp. 104.

Burone, L., Muniz, P., Pires-Vanin, A.M.S. and Rodrigues, M., 2003. Spatial distribution of organic matter in the surface sediments of Ubatuba Bay (Southeastern Brazil). Annls Brazil. Acad. Sci., 75: 77-90. https://doi.org/10.1590/S000137652003000100009

Burton, G.A.J.R., Gunnison, D. and Lanza, G.R., 1987. Survival of pathogenic bacteria in various freshwater sediments. Appl. environ. Microbiol., 53: 633-638. https://doi.org/10.1128/AEM.53.4.633638.1987

Chatelet, E.R., Bout-Roumazeilles, V., Riboulleau, A. and Trentesaux, A., 2008. Sediment (grain size and clay mineralogy) and organic matter quality control on living benthic foraminifera. Revue de Micropaléontologie, 52: 75-84. https://doi. org/10.1016/j.revmic.2008.10.002

Darnley, A.G., Bjorklund, A.J., Bolviken, B., Gustavsson, N., Koval, P., Plant, J. A., Steenfelt, A., Tauchid, M. and Xuejing, X., 1995. Global geochemical database: For environmental and resource management. recommendation for international geochemical mapping. IGCP 259/360 final report, 122 p., UNESCO Publ., Paris. 07A. DIN 38 414-S11 (1987) Probenahme von Sedimenten: Sampling of sediments. Berlin. pp. 7. Davies, C.M. and Bavor, H.J., 2000. The fate of storm 
water-associated bacteria in constructed wetland and water pollution control pond systems. J. appl. Microbiol., 89: 349-360. https://doi.org/10.1046/ j.1365-2672.2000.01118.x

Davies, C.M. and Evison, L.M., 1991. Sunlight and the survival of enteric bacteria in natural waters. J. appl. Bact., 70: 265-274. https://doi. org/10.1111/j.1365-2672.1991.tb02935.x

Davies, C.M., Long, J.A., Donald, M. and Ashbolt, N.J., 1995. Survival of fecal microorganisms in marine and freshwater sediments. Appl. environ. Microbiol., 61: 1888-1896. https://doi.org/10.1128/ AEM.61.5.1888-1896.1995

Davies-Colley, R.J., Donnison, A.M., Speed, D.J., Ross, C.M. and Nagels, J.W., 1999. Inactivation of faecal indicator microorganisms in waste stabilisation ponds: Interactions of environmental factors with sunlight. Water Res., 33: 1220-1230. https://doi. org/10.1016/S0043-1354(98)00321-2

Faust, M.A., Aotaky, A.E. and Hargadon, M.T., 1975. Effect of physical parameters on the in situ survival of Escherichia coli MC-6 in an estuarine environment. Appl. Microbiol., 30: 800-806. https://doi.org/10.1128/AEM.30.5.800-806.1975

Garzio-Hadzick, A., Shelton, D.R., Hill, R.L., Pachepsky, Y.A., Guber, A.K. and Rowland, R., 2010. Survival of manure-borne E. coli in streambed sediment: Effects of temperature and sediment properties. Water Res., 44: 2753-2762. https://doi.org/10.1016/j.watres.2010.02.011

Gerba, C.P. and McLeod, J.S., 1976. Effect of sediments on the survival of Escherichia coli in marine waters. Appl. environ. Microbiol., 32: 114-120. https://doi. org/10.1128/AEM.32.1.114-120.1976

Grimes, D.J., 1975. Release of sediment-bound fecal coliforms by dredging. Appl. Microbiol., 29: 109-111. https://doi.org/10.1128/AEM.29.1.109111.1975

Gyu, Y., Kim, S., Un, D., Sick, J., Jun, H., Woo, M., Hak, B., Hyun, M. and Ho, Y., 2014. Decalcification of benthic foraminifera due to Hebei spirit oil spill, Korea. Mar. Pollut. Bull., 87: 276-285. https://doi. org/10.1016/j.marpolbul.2014.07.044

IAEA, 2003. Collection and preparation of bottom sediment samples for analysis of radionuclides and trace elements. International Atomic Energy Agency, Vienna International Centre, Vienna, -Tecdoc-1360

Jones, G.E. 1964. Effect of chelating agents on the growth of Escherichia coli in seawater. J Bact., 87: 483-499. https://doi.org/10.1128/JB.87.3.483499.1964
Kazemi Rad, L., Mohammadi, H. and Teyfoori, V., 2015. Impacts of climate change on droughts in Gilan Province. Ecol. Balkan., Iran, 7: 29-38.

Konert, M. and Vandenberghe, J., 1997. Comparison of laser grain size analysis with pipette and sieve analysis: A solution for the underestimation of the clay fraction. Sedimentology, 44: 523-535. https:// doi.org/10.1046/j.1365-3091.1997.d01-38.x

Laroche, O., Wood, S., Tremblay, L., Ellis, J., Lejzerowicz, F., Pawlowski, J., Lear, G., Atlas, J. and Pochon, X., 2016. First evaluation of foraminiferal metabarcoding for monitoring benthic impacts at an offshore oil drilling site. Mar. environ. Res., 120: 225-235. https://doi. org/10.1016/j.marenvres.2016.08.009

Lee, A., and Nikraz, H., 2015. BOD: COD Ratio as an Indicator for River Pollution. Int. Proc. chem. Biol. environ. Eng., 51: 139-142.

Li, Y., Gang, T., BI, H., Lin, W., Peng, W., YE, J. and Chun, C., 2015. Responses of benthic foraminifera to the 2011 oil spill in the Bohai Sea. Mar. Pollut. Bull., 96: 245-260. https://doi.org/10.1016/j. marpolbul.2015.05.020

Li, T., Xiang, R. and Li, T., 2014. Influence of trace metals in recent benthic foraminifera distribution in the Pearl River Estuary. Mar. Micropaleontol., 108: $\quad 13-27 . \quad$ https://doi.org/10.1016/j. marmicro.2014.02.003

Lipps, J.H. and Valentine, J.W., 2007. The role of Foraminifera in the trophic structure of marine communities, Lethaia, 3: 279-286. https://doi. org/10.1111/j.1502-3931.1970.tb01271.x

Loeblich, A.R. and Tappan, H., 1988. Foraminifera genera and their classification. Van Nost rand Reinhold Company, New York.v.2.970. https://doi. org/10.1007/978-1-4899-5760-3

Lutze, G.F. and Altenbach, A.V., 1991. Technik und Signifikanz der Lebendfärbung benthischer Foraminiferen mit Bengalrot. Geol. Jahrb. Reihe A., 128: 251-265 (In German, with a short english abstract and two color plates).

Magurran, A.E., 1988. Ecological diversity and its measurement. Princeton University Press, Princeton, N.J. https://doi.org/10.1007/978-94015-7358-0

Marino, R.P., Gannon, J.J., 1991. Survival of fecalcoliforms and fecal streptococci in storm-drain sediment. Water Res., 25: 1089-1098. https://oi. org/10.1016/0043-1354(91)90202-2

Martin, R.A. and Nesbitt, E.A., 2015. Foraminiferal evidence of sediment toxicity in anthropogenically influenced embayments of Puget Sound, Washington, 
U.S.A. Mar. Micropaleontol., 121: 97-106. https:// doi.org/10.1016/j.marmicro.2015.11.002

Moghaddasi, B., Fatemi, S.M.R., and Vosoughi, G.H., 2008. Study on the diversity and distribution of benthic foraminifera in the offshore sediments of the continental shelf in the Oman Sea, Islamic Azad university of Ahvaz, 1: 13-27.

National Centers for Environmental Information, 2019. Available at: https://www.ncdc.noaa.gov/tempand-precip/ (accessed 10 Sep. 2019).

Nigam, R., Linshy, V.N., Kurtarkar, S.R. and Saraswat, R., 2009. Effects of sudden stress due to heavy metal mercury on benthic foraminifer Rosalina leei: Laboratory culture experiment. Mar. Pollut. Bull., 59: 362-368. https://doi.org/10.1016/j. marpolbul.2009.08.014

Pommepuy, M., Guillaud, J.F., Dupray, E., Derrien, A., Le, Guyader, F. and Cormier, M., 1992. Enteric bacteria survival factors. Wat. Sci. Tech., 25: 93103. https://doi.org/10.2166/wst.1992.0341

Pote, J., Haller, L., Kottelat, R., Sastre, V., Arpagaus, P. and Wildi, W., 2009. Persistence and growth of faecal culturable bacterial indicators in water column and sediments of Vidy Bay, Lake Geneva, Switzerland. J. environ. Sci., (China) 21: 62-69. https://doi.org/10.1016/S1001-0742(09)60012-7

Raja, B.C.S., Jayaraju, N., Sreenivasulu, G., Suresh, U. and Reddy, A.N., 2016. Heavy metal pollution monitoring with foraminifera in the estuaries of Nellore coast, East coast of India. Mar. Pollut. Bull., 113: 542-551. https://doi.org/10.1016/j. marpolbul.2016.08.051

Roper, M.M. and Marshall, K.C., 1974. Modification of the interaction between Escherichia coli and bacteriophage in saline sediments. Microbial Ecol., 1: 1-13. https://doi.org/10.1007/BF02512375

Sadoughö M., Ghane, F., Manouchehri, H., Moghaddasi, B. and Beikaee, H., 2013. Identification and abundance of benthic foraminifera in the sediments from fereidoonkenar to Babolsar of Southern Caspian Sea, Turk. J. Fish. aquat. Sci., 13: 79-86.

Schumacher, B.A., 2002. Methods for the determination of total organic carbon (TOC) in soils and sediments. U.S. Environmental Protection Agency,
Washington, DC, EPA/600/R-02/069 (NTIS PB2003-100822).

Schintu, M., Marrucci, A., Marras, B., Galgani, F., Buosi, C., Ibba, A. and Cherchi, A., 2016. Heavy metal accumulation in surface sediments at the port of Cagliari (Sardinia, western Mediterra nean): Environmental assessment using sequential extractions and benthic foraminifera. Mar. Pollut. Bull., 111: 45-56. https://doi.org/10.1016/j. marpolbul.2016.07.029

Shuval, H., 2003. Estimating the global burden of Thalassogenic diseases: human infectious diseases caused by wastewater pollution of the marine environment. J. Water Hlth., 1: 53-64. https://doi. org/10.2166/wh.2003.0007

Solution for the underestimation of the clay fraction. Sedimentology, 44: 523-535.

Smith, K.L., Huffard, C.L., Sherman, A.D. and Ruhl, H.A., 2016. Decadal change in sediment community oxygen consumption in the Abyssal Northeast Pacific. Aquat. Geochem., 22: 401-417. https://doi.org/10.1007/s10498-016-9293-3

Titelboim, D., Almogi-Labin, A., Herut, B., Kucera, M., Schmidt, C., Hyams-Kaphzan, O., Ovadia, O., and Abramovich, S., 2016. Selective responses of benthic foraminifera to thermal pollution. Mar. Pollut. Bull., 105: 324-336. https://doi. org/10.1016/j.marpolbul.2016.02.002

Uthicke, S., Patel, F. and Ditchburn, R., 2012. Elevated land runoff after European settlement perturbs persistent foraminiferal assemblages on the Great Barrier Reef. Ecology, 93: 111-121. https://doi. org/10.1890/11-0665.1

Vitousek, P.M., Mooney, H.A., Lubchenco, J. and Melillo, J.M., 1997. Human domination of earth's ecosystems. Science, 277: 494-499. https://doi. org/10.1126/science.277.5325.494

Yahiya, M. and Miranda, M.T.P., 2016. Planktons as indicators of heavy metal pollution along south west coast of India. Int. J. Sci. Res., 5: 977-982.

Youssef, M., 2015. Heavy metals contamination and distribution of benthic foraminifera from the Red Sea coastal area. Oceanologia, 57: 236-250. https://doi.org/10.1016/j.oceano.2015.04.002 